\title{
Концептуальная модель государственно-частного партнерства в сфере туризма
}

\author{
А.Т. Тлеубердинова ${ }^{1}$, А.Т. Алдабергенова ${ }^{2}$, Д.М. Салауатова ${ }^{2}$ \\ ${ }^{1}$ Институт экономики» Комитета науки Министерства образования и науки Республики Казахстан, ${ }^{2}$ \\ Карагандинский экономический университет Казпотребсоюза
}

\begin{abstract}
Аннотация
Развитию сферы туризма может содействовать оптимизация ее управления на основе государственночастного партнерства, как одной из наиболее эффективных форм мобилизации государства и бизнеса для решения задач развития туризма.

В статье проведен всесторонний анализ теоретических основ механизма государственно-частного партнерства и его особенностей, в частности, в туризме. На основе анализа зарубежных, российских и отечественных источников был выявлен ряд подходов формулировки термина «государственно-частное партнерство». Определены преимущества партнерства для государства и бизнеса в сфере туризма.

Цель исследования - теоретический обзор роли и значения государственно-частного партнерства для развития туристской отрасли и разработка концептуальной модели государственно-частного партнерства в сфере туризма.

Результатом исследования стала разработка концептуальной модели государственно-частного партнерства для туристской отрасли, которая может послужить теоретико-методологической основой реализации стратегического курса по развитию туристской отрасли. Результаты исследования могут быть использованы при разработке государственных и региональных программ развития туристской отрасли.

Ключевые слова: туристская отрасль, государственно-частное партнерство, модель государственночастного партнерства, функции государственно-частного партнерства в туризме, цели партнерских отношений в туризме.
\end{abstract}

\section{Туризмдегі мемлекеттік-жекешелік әріптестіктің тұжырымдамалық моделі} Түйін

Қазақстанда туризм саласының дамуына мемлекет пен бизнесті туризмді дамыту мәселелерін шешуге жұмылдырудың тиімді формаларының бірі ретінде мемлекеттік-жекешелік әріптестік негізінде оны басқаруды оңтайландыру ықпал етуі мүмкін.

Мақалада мемлекеттік-жекешелік әріптестік тетігінің теориялық негіздеріне және оның туризм саласындағы жұмыс істеу ерекшеліктеріне жан-жақты талдау жүргізілді. Шетелдік, ресейлік және отандық дереккөздерді талдау негізінде «мемлекеттік-жекешелік әріптестік» терминін тұжырымдаудың бірқатар тәсілдері анықталды. Туризм саласындағы мемлекет пен бизнес үшін серіктестіктің артықшылықтары анықталды.

Зерттеудің мақсаты - туристік индустрияны дамытуда мемлекеттік-жекешелік әріптестіктің рөлі мен маңызына теориялық шолу және туризмдегі мемлекеттік-жекешелік әріптестіктің тұжырымдамалық моделін жасау.

Зерттеудің нәтижесі туристік индустрияны дамытудың стратегиялық курсын жүзеге асырудың теориялық және әдіснамалық негізі бола алатын туристік индустрия үшін мемлекеттік-жекешелік әріптестіктің тұжырымдамалық моделін жасау болды. Зерттеу нәтижелерін туристік индустрияны дамытудың мемлекеттік және аймақтық бағдарламаларын әзірлеу кезінде пайдалануға болады.

Түйін сөздер: туризм саласы, мемлекеттік-жекешелік әріптестік, мемлекеттік-жекешелік әріптестік моделі, туризмдегі мемлекеттік-жекешелік әріптестік функциялары, туризмдегі әріптестік қатынастардың мақсаттары.

\section{Conceptual model of public-private partnership in tourism}

\section{Summary}

The development of the tourism sector in Kazakhstan can be facilitated by the optimization of its management on the basis of public-private partnership, as one of the most effective forms of mobilizing the state and business to solve the problems of tourism development.

The article provides a comprehensive analysis of the theoretical foundations of the mechanism of public-private partnership and the specifics of public-private partnership in tourism, in particular. Based on the analysis of foreign, Russian and domestic sources, a number of approaches to the formulation of the term "public-private partnership»" were identified. The advantages of partnership for the state and business in the field of tourism are determined.

The purpose of the study is theoretical review of the role and significance of public-private partnerships for the development of the tourism industry and the design of a conceptual model of public-private partnerships in tourism.

The result of the research was the design of a conceptual model of public-private partnership for the tourism industry, which can serve as a theoretical and methodological basis for the implementation of a strategic course for the development of the tourism industry. The research results can be used in the development of state and regional programs for the development of the tourism industry.

Keywords: tourism industry, public-private partnership, model of public-private partnership, functions of publicprivate partnership in tourism, goals of partnership in tourism. 


\section{Введение}

Пандемия COVID-19 нанесла существенный ущерб как здоровью населения, так и экономике многих стран. Коронокризис создал множество проблем, как социальных, связанных с болезнью и увеличением смертности среди населения, потерей рабочих мест, снижением платежеспособности казахстанцев, так и экономических, обнаживших необходимость ускорения диверсификации страны, отхода от сырьевой ориентации и зависимости от конъюнктуры мировых рынков. Анализ данных официальной статистики за последние 5 лет характеризуется положительной динамикой по всем видам туризма, причем темп прироста внутреннего туризма составил $34 \%$, а также ожидается его рост в пандемийный и постпандемийный период.

Одним из направлений, дающих возможность нахождения решения в сложившейся ситуации, является развитие туризма, а именно внутреннего туризма. Развитие внутреннего туризма составляет значительный социально-экономический эффект, выражающийся в создании новых предприятий, увеличении рабочих мест, росте налоговых поступлений в бюджет, оказывает мультипликационное воздействие на развитие смежных отраслей, а также обеспечивает доступность отдыха для собственных граждан.

Государственная программа развития туристской отрасли Республики Казахстан на 2019-2025 годы ставит целью достижение доли туризма в общем объеме ВВП Республики Казахстан не менее $8 \%$. В сложившейся ситуации с последствиями пандемии, ограничением передвижения в зарубежные страны, опасениями заражения населения, есть реальная возможность увеличения количества внутренних туристов в разы.

Очевидно, что эпидемия будет иметь масштабные последствия для экономики мира и Казахстана. Специалисты ООН считают, что из-за COVID-19 без работы могут остаться 195 млн человек, а уровень безработицы и бедности может стать «историческим». Такие прогнозы дальнейшего ухудшения социальноэкономического положения в стране определяют необходимость поиска решений, в условиях неопределенности временного горизонта экономического кризиса, вопросов новой экономической модели развития и социальной поддержки населения страны: оздоровления переболевших людей, проблем безработицы, снижения доходов.

В данной ситуации особое значение приобретает государственно-частное партнерство. Современные условия требуют от государства и частного сектора активизации деятельности, направленной на увеличение эффективности функционирования экономики, совершенствование социальной сферы. Поддержка в рамках государственно-частного партнерства способна решить вопросы оздоровления национальной экономики и улучшения благосостояния населения страны.

Государственно-частное партнерство (англ. - Public-private partnership) предполагает сотрудничество между государственным и частным сектором для выполнения долгосрочных задач, обычно направленных на развитие отрасли или региона. Причины создания такого партнерства могут быть разные, но наиболее значимыми являются: передача ноу-хау и финансовая помощь от частных партнеров и государственных органов. Данный тип партнерства очень часто стал использоваться в последнее время в различных странах, как антикризисный инструмент.

\section{Литературный обзор}

Теоретический обзор существующих определений позволил выделить несколько подходов формулировки дефиниции «государственно-частное партнерство» (ГЧП), позволяющих объяснить логическую последовательность ее развития (таблица 1).

Ключевым толкованием дефиниции является партнерство между государственным и частным секторами с целью реализации общественно-значимого проекта или услуги, традиционно предоставляемой государственным сектором. Данная формулировка дана и в Законе Республики Казахстан о государственно-частном партнерстве от 31 октября 2015 года № 379-V ЗРК [1].

Аналогичного смыслового содержания дефиниции придерживается и Национальная палата предпринимателей Республики Казахстан «Атамекен», дополнительно указывая на необходимость сбалансированного распределения рисков, выгод и затрат, прав и обязанностей, определяемых в соответствующих договорах [2]. Часто термин «форма сотрудничества» авторами заменяется на «организационный альянс», что, в принципе, не меняет основную смысловую нагрузку. 
Таблица 1 - Обзор определений термина «государственно-частное партнерство»

\begin{tabular}{|c|c|c|c|}
\hline № & $\begin{array}{c}\text { Основное содержание } \\
\text { определения }\end{array}$ & Авторы & Комментарии автора \\
\hline 1 & 2 & 3 & 4 \\
\hline 1 & $\begin{array}{l}\text { Форма сотрудничества } \\
\text { между государственным } \\
\text { партнером и частным } \\
\text { партнером }\end{array}$ & $\begin{array}{l}\text { IСАО [3], Группа Всемирного банка. } \\
\text { Правовой ресурсный центр госу- } \\
\text { дарственно-частного партнерства [4], } \\
\text { Издательство Investopedia [5], ОЭСР } \\
\text { [6], МВФ [7], Европейская Комиссия } \\
\text { [8], Э.Сава [9], Э. Клин и Г.Тейсман } \\
{[10], \text { Хэм Х. Ван, Коппенджан Дж. }} \\
\text { [11], Сайфуллин Р.И. [12, с. 313], } \\
\text { Ефимова Н.Ф., Маховикова Г.А. [13], } \\
\text { Ковальчук А.П, Никольская Е.Ю. } \\
\text { [14] }\end{array}$ & $\begin{array}{l}\text { Наиболее распространенное } \\
\text { определение ГЧП, предполагающее } \\
\text { реализацию сложных, } \\
\text { многопартнерских проектов в целях } \\
\text { развития территорий и улучшения } \\
\text { условий жизни населения, в рамках } \\
\text { которой традиционные роли } \\
\text { государства и частного сектора } \\
\text { перераспределяются }\end{array}$ \\
\hline 2 & $\begin{array}{l}\text { Институциональный и } \\
\text { организационный альянс } \\
\text { государственной власти и } \\
\text { частного бизнеса }\end{array}$ & $\begin{array}{l}\text { Дерябина М. [15], Питанов В.А. [16], } \\
\text { Ходж Г., Грив К. [17], Антонова К.А. } \\
\text { [18], Болехов И.Е. [19], Ларин С.Н. } \\
\text { [20], Лонг П. [21], Кернагхэм К. [22], } \\
\text { Витт С., Моутиньо Л. [23] }\end{array}$ & $\begin{array}{l}\text { Смысловое содержание идентично } \\
\text { предыдущему подходу, основное } \\
\text { отличие заключается только в } \\
\text { используемом ключевом термине }\end{array}$ \\
\hline 3 & $\begin{array}{l}\text { Юридически оформленная } \\
\text { на фиксированный срок } \\
\text { система взаимоотношений } \\
\text { между государством и } \\
\text { юридическими лицами }\end{array}$ & $\begin{array}{l}\text { Варнавский В. [24], Белицкая А.В. } \\
\text { [25], РРР Кnowledge Lab [26], } \\
\text { Министерство экономического } \\
\text { развития РФ [27], Резниченко Н.В. } \\
\text { [28], Сытых М. С. [29], Пилякина } \\
\text { В.С. [30], Кабашкин В.А. [31] }\end{array}$ & $\begin{array}{l}\text { Данный подход подчеркивает } \\
\text { официальное свойство отноше- } \\
\text { ний, определенное законодательст- } \\
\text { вом, дает наиболее детальное } \\
\text { определение форм собственности, } \\
\text { поставленных задач, предостав- } \\
\text { ляемых услуг, значимости реали- } \\
\text { зуемых проектов для государства и } \\
\text { местного сообщества }\end{array}$ \\
\hline 4 & $\begin{array}{l}\text { Долгосрочный контракт } \\
\text { между государством и } \\
\text { частным сектором, в кото- } \\
\text { ром ресурсы и риски рас- } \\
\text { пределяются для целей } \\
\text { развития общественной } \\
\text { инфраструктуры }\end{array}$ & $\begin{array}{l}\text { Акинтое А. и др. [31], Мейдуте И., } \\
\text { Палиулис Н. [32], Чапман М. [33] }\end{array}$ & $\begin{array}{l}\text { Определение, близкое по основному } \\
\text { содержанию к предыдущим, но } \\
\text { предусматривающее длитель- } \\
\text { ность реализации проектов, рас- } \\
\text { пределение ресурсов и рисков }\end{array}$ \\
\hline 5 & $\begin{array}{l}\text { Комплексный механизм } \\
\text { сотрудничества госу- } \\
\text { дарственного и частного } \\
\text { партнера в интересах } \\
\text { государства }\end{array}$ & $\begin{array}{l}\text { Сазонов В. [34], Зельднер А.Г., } \\
\text { Смотрицкая И.И. [35], Геррард М. } \\
\text { [36] }\end{array}$ & $\begin{array}{l}\text { Формулировка, подчеркивающая } \\
\text { свойство комплексного воздействия } \\
\text { на систему взаимоотношений, } \\
\text { конечной целевой направленностью } \\
\text { которой является решение госу- } \\
\text { дарственных задач, в результате } \\
\text { которого формируется и усилива- } \\
\text { ется ресурсный потенциал сотруд- } \\
\text { ничества }\end{array}$ \\
\hline 6 & $\begin{array}{l}\text { Система отношений } \\
\text { между государственным } \\
\text { и частным секторами, } \\
\text { предполагающая разде- } \\
\text { ление рисков и вознаграж- } \\
\text { дений для достижения } \\
\text { желаемых результатов }\end{array}$ & $\begin{array}{l}\text { Standard \& Poor’s [8], Европейский } \\
\text { инвестиционный банк [8], Вuilding } \\
\text { Better Partnerships [37], Шамков Ю. } \\
\text { В. [38], Гримси Д., Льюис М. [39], } \\
\text { Бруссер П., Рожкова С. [40] }\end{array}$ & $\begin{array}{l}\text { Определение, предусматривающее } \\
\text { переход традиционных хозяйст- } \\
\text { венных взаимоотношений на но- } \\
\text { вый уровень, в котором частная } \\
\text { сторона несет значительный риск, } \\
\text { а ответственность руководства } \\
\text { и вознаграждение связаны с } \\
\text { результатами деятельности }\end{array}$ \\
\hline 7 & $\begin{array}{l}\text { Объединение материаль- } \\
\text { ных и нематериальных ре- } \\
\text { сурсов общества (государс- } \\
\text { тва или местного самоуп- } \\
\text { равления) и частного сек- } \\
\text { тора на долговременной и } \\
\text { взаимовыгодной основе для } \\
\text { создания общественных благ }\end{array}$ & Дынин Е. [41], Амерханова А.Б. [42] & $\begin{array}{l}\text { Основное внимание уделено объе- } \\
\text { динению ресурсов, направленному } \\
\text { на благоустройство и развитие тер- } \\
\text { риторий, развитие инженерной } \\
\text { и социальной инфраструктуры, } \\
\text { а также оказание общественных } \\
\text { услуг (образование, здравоохране- } \\
\text { ние и т.д.) }\end{array}$ \\
\hline
\end{tabular}




\begin{tabular}{|c|c|c|c|}
\hline 1 & 2 & 3 & 4 \\
\hline 8 & $\begin{array}{l}\text { Альтернатива приобрете- } \\
\text { нию объектов инфраструк- } \\
\text { туры государственным } \\
\text { сектором (государственным } \\
\text { закупкам), которые финан- } \\
\text { сируются за счет налого- } \\
\text { вых поступлений или } \\
\text { государственных займов }\end{array}$ & $\begin{array}{l}\text { Йескомб Э.Р. [43], Министерство } \\
\text { туризма, культуры и рекреаций } \\
\text { провинции Онтарио [44], Ким Д., } \\
\text { Ким, Ли Т. [45], Линдер С. [46], Де } \\
\text { Лэси Т.,М. Бэттинг, С. Мор, } \\
\text { С. Ноакис [47]. }\end{array}$ & $\begin{array}{l}\text { Формулировка популярная для } \\
\text { западных исследователей с } \\
\text { описанием механизма реализации } \\
\text { ГЧП и целей участников сотруд- } \\
\text { ничества }\end{array}$ \\
\hline 9 & $\begin{array}{l}\text { Один из ключевых } \\
\text { инструментов формирова- } \\
\text { ния кластеров }\end{array}$ & Хлунов А.В. [48]. & $\begin{array}{l}\text { Оригинальный подход, ориенти- } \\
\text { рованный на формирование } \\
\text { системы региональных научно- } \\
\text { образовательных центров, приз- } \\
\text { ванных объединить усилия для } \\
\text { внедрения результатов совместных } \\
\text { исследований в производство }\end{array}$ \\
\hline
\end{tabular}

Существуют определения, акцентирующие внимание на юридическом оформлении соглашения уполномоченным органом и соответствии нормам действующего законодательства. Есть точки зрения о первичности объединения ресурсов, обозначения рисков в решении общественных задач и др.

Тем не менее, несмотря на имеющиеся отдельные отличительные детали, большинство авторов едины во мнении о том, что ГЧП представляет собой комплекс способов взаимовыгодного сотрудничества государственных структур и частных компаний, направленных на реализацию широкого спектра проектов социальной и экономической инфраструктуры.

Анализ существующих подходов к определению государственно-частного партнерства позволил сформулировать собственное определение: государственно-частного партнерства в сфере туризма - это объединение усилий государства и частного сектора по рациональному использованию туристскорекреационных ресурсов на долговременной и взаимовыгодной основе для развития туристской отрасли.

\section{Методология}

Исследование проведено с использованием системного подхода, в основе которого лежит исследование объектов как систем, описательного, сравнительного методов и метода группировки. Анализ базируется на основе систематизащии подходов к определению государственно-частного партнерства зарубежных, российских и отечественных yченых. Системный подход ориентирует исследование на раскрытие особенностей и преимуществ отношений государства и частного сектора, на выявление многообразных типов связей государства и частного сек- тора и сведение их в единую теоретическую картину - концептуальную модель государственно-частного партнерства в сфере туризма. В работе были изучены теоретикометодологические аспекты и зарубежный опыт формирования и реализации механизма государственно-частного партнерства в сфере туризма.

\section{Результаты и обсуждение}

Частное финансирование может поддержать увеличение инвестиций в инфраструктуру без соответствующего увеличения государственного займа и долга, а также стать источником государственных доходов. Кроме того, гибкое управление в частном секторе, его способность к инновациям может привести к повышению эффективности, обеспечивающей, в свою очередь, сочетание лучшего качества и более дешевых услуг. Для частного сектора ГЧП повышает возможности для бизнеса в тех районах и сферах, из которых он во многих случаях ранее мог быть исключен [49].

Принципами ГЧП, которые должны обеспечивать эффективное использование ресурсов партнерами для получения взаимной выгоды, являются:

- отсутствие дискриминации, обеспечивающее равные условия для всех участников государственно-частного партнерства и возможность стать подрядчиком, способствующее проявлению реальной конкуренции для любого оператора;

- равенство прав, предусматривающее установление и заключение правил, требований, критериев ГЧП для всех операторов, направленных на обеспечение равных возможностей;

- прозрачность, т.е. обеспечение доступа всей информации о процедурах подачи зая- 
вок на заключение договоров о государственночастном партнерстве;

- соразмерность, предполагающая обеспечение справедливого соотношения между целями государственного партнера, договором государственно-частного партнерства и запрошенными требованиями, гарантирующим баланс между целью договора и фактическим спросом, условиями контракта;

- эффективное использование средств, т.к. процедуры заключения договоров ГЧП и использование критериев должны отражать экономическую выгоду от получения желаемого результата с учетом конкретных эффектов, прежде всего, в социальной сфере, защите окружающей среды, продвижении устойчивого развития;

- подотчетность, т.е. определение обязанностей, ответственности сторон, участвующих в реализации договоров государственно-частного партнерства, направленное на обеспечение профессионализма, беспристрастности, независимости принимаемых в ходе процесса решений.

Сегодня ГЧП по праву считается «творческим альянсом» между государством и частным бизнесом для достижения общей цели. К такому партнерству могут присоединяться и другие участники, в том числе неправительственные учреждения, такие как поставщики медицинских услуг и образовательные учреждения; некоммерческие ассоциации, общественные организации; заинтересованные граждане и местные сообщества. Партнерские отношения способствуют успешной реализации мероприятий от отдельных проектов до долгосрочных планов землепользования и экономического роста.

Роль государственных учреждений в ГЧП заключается в предоставлении услуг в интересах общества, отвечающих требованиям рыночного механизма, с одной стороны, удовлетворении общественной потребности, с другой, посредством сокращения государственных расходов и повышения качества государственных услуг [50].

Государственные органы власти традиционно берут на себя ответственность за предоставление услуг населению, инфраструктурное и территориальное развитие и др. В случае государственно-частного партнерства, предоставление государственных услуг, требующих значительных инвестиций, а также несение связанных с этим рисков делегируется частному сектору на долгосрочной основе [33]. Механизм функционирования государственно-частного партнерства хорошо иллюстрирует модель, предложенная И. Мейдуте и Н. Палиулис (рисунок 1).

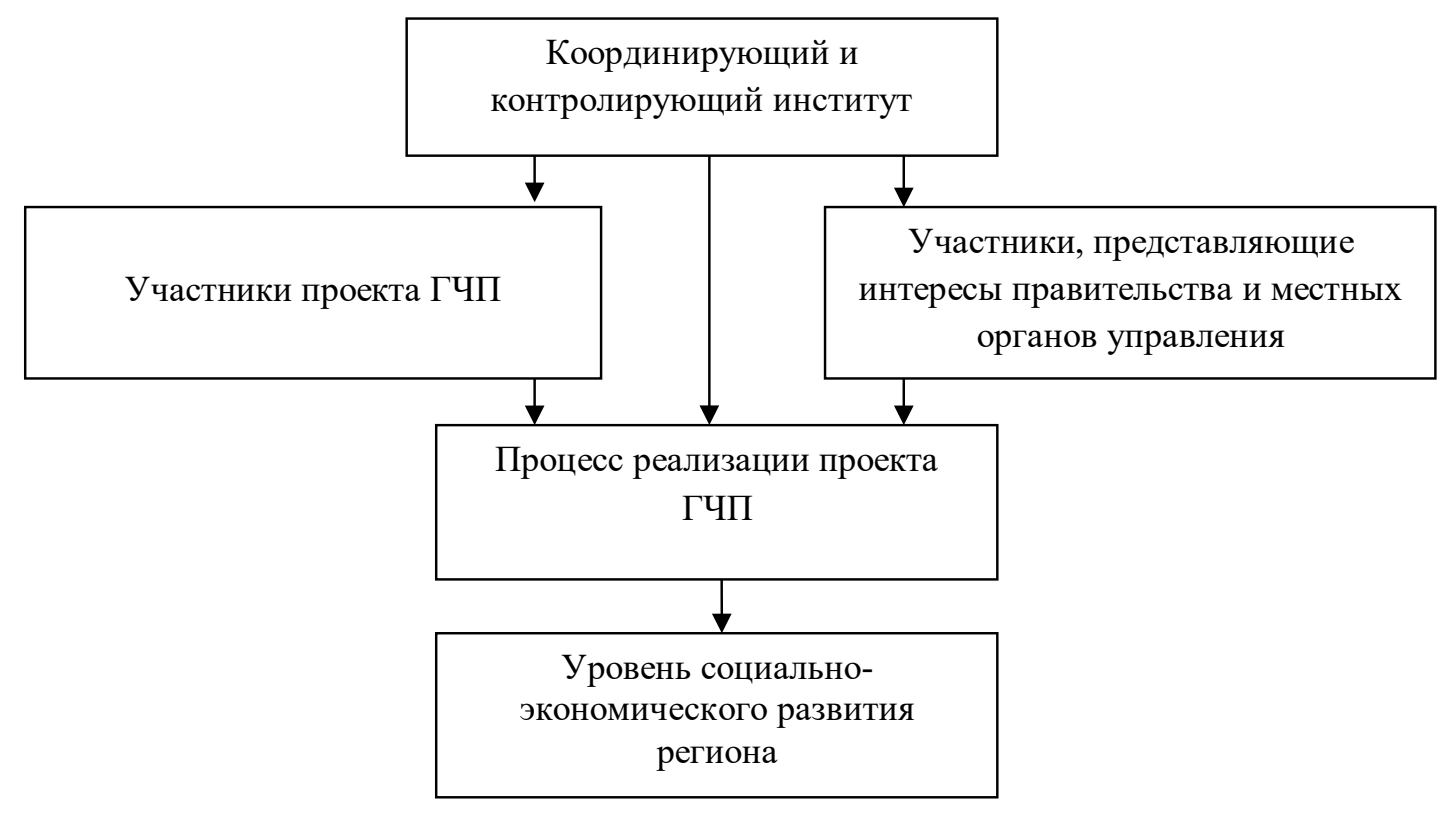

Примечание - составлено авторами на основе источника [33]

Рисунок 1 - Модель государственно-частного партнерства 
Государственно-частное партнерство предоставляет новые инновационные возможности финансирования посредством открытия новых каналов привлечения капитала, учета специфики рынка в формировании затрат, передачи риска наиболее сильным игрокам, оптимизации соотношения цены и качества.

К ключевым достоинствам ГЧП относят следующие:

1. гарантированное достижение peзультатов со стороны частных партнеров;

2. оптимальное распределение рисков между партнерами, располагающими соответствующими знаниями, опытом и способностью брать на себя риски;

3. интеграция проектирования, строительства, эксплуатации и обслуживания в целях экономии затрат и обеспечения выполнения;

4. частное финансирование, обеспечивающее свободный доступ к капиталу и финансам.

Государственный сектор обеспечивает преимущества участия частного сектора, сохраняя при этом государственный контроль и общественную собственность на строящиеся объекты и результаты реализуемого проекта, что позволяет ускорить график строительства и модернизации инфраструктуры.

Дополнительными преимуществами практики государственно-частного партнерства можно назвать:

1. Жесткие правила лимитирования затрат. Для коммерческих предприятий, как правило, бюджетные ограничения являются более жесткими и обязывающими, не допускающими перерасход средств, поэтому затраты на строительство общественных проектов более четко определены.

2. Жесткие стандарты информации и проверки. Модель ГЧП включает более строгое информационное обеспечение и действия по проверке реализации проектов. Эту задачу берут на себя частные партнеры и инфраструктурные агентства правительства.

3. Новый способ управления рисками. Риски могут быть переданы частным партнерам. Как правило, именно они несут риски и ответственность за результаты. Передача риска в частный сектор означает, что они перекладываются на тех, кто обладает возможностями, чтобы справиться с ними, в результате чего риск сводится к минимуму, а затраты контролируются. Учитываются следующие основные критерии: во-первых, агент, который должен нести риск, лучше всего способен повлиять на результат, связанный с риском; во-вторых, риск должен нести агент, способный нести риск с минимальными затратами. Если распределение рисков предназначено для установления финансового равновесия между партнерами, неправильное распределение рисков может увеличить затраты и привести к удлинению сроков реализации проекта.

4. Решение сложных узкоспециализированных задач передается компетентным специалистам. Компании, специализирующиеся на определенных типах рискованных проектов, могут принять их в масштабе, превосходящем возможности правительств.

5. Частная управленческая экспертиза государственных проектов. ГЧП предоставляет управленческий рынок труда частного сектора в распоряжение государственных проектов. Талант, опыт и знания на этом рынке образуют мощную поддержку в дополнение к вопросу об экспертизе государственного сектора. Подобное сотрудничество позволяет выполнять проекты вовремя и с долгосрочной экономией средств.

6. Бюджетная предсказуемость. Модель ГЧП вводит сильный элемент бюджетной определенности в поддержании активов, что позволяет избежать соблазн перераспределить средства для покрытия других областей бюджетного дефицита.

7. Акцент на результаты, а не на процесс, в итоге частные партнеры вынуждены выбирать рентабельные методы производств.

8. Предоставление новых возможностей для инвесторов. Проекты государственночастного партнерства привлекают новых партнеров через генерируемые инвестиции, привлекательные за счет своей предсказуемости и хорошей окупаемости. Как правило, инвесторы могут рассчитывать на длительный срок службы активов. Кроме того, масштаб проектов ГЧП обычно велик, что часто требует совместного инвестиционного подхода от инвесторов, в результате чего снижается риск потери капитала [51].

Государственно-частное партнерство используется для решения многих задач развития различных отраслей, в том числе и туризма, признанного во многих странах одним из наиболее актуальных экономических и социологических явлений современности и характеризующегося как сектор со значительным потенциалом социально-экономического развития. Он представляет собой структурный элемент динамики мировой экономики, поскольку стал одним из наиболее важных ее секторов. 
Общепризнан вклад туристских прибытий развитой туристской отрасли в доходную часть казны государства. Весьма значительную роль отрасль играет в повышении занятости и доходов населения страны. Нельзя не учитывать содействие туризма формированию положительного образа страны на мировой арене и воспитательное значение для собственных граждан. Если на национальном уровне привлекательность туризма признается высокой, то на местном уровне данный сектор представляет собой важный инструмент регионального развития, стимулирующий к использованию потенциала регионов. В этом контексте государственно-частное партнерство играет важную роль для решения подобных задач.

Важность стратегического союза государственных структур и частного сектора в туризме значительно возрастает в условиях развития таких факторов, как обострение международной конкуренции, ускорение технического прогресса, повышение зависимости от клиентов и поставщиков. Развитие туристской отрасли, как правило, имеет долгосрочный характер и длительные сроки окупаемости. Поэтому для продвижения долгосрочного стратегического мышления, результаты которого должны быть гибкими и новаторскими, отвечающими первоначальным потребностям и ожиданиям, актуальное значение имеют партнерские отношения, включающие разделение власти, совместной работы, информационной поддержки для достижения общих целей или взаимной выгоды [22, 34].

Партнерство может быть инициировано по нескольким причинам:

- снижение риска и затрат при выходе на новые рынки за счет увеличения финансовых и человеческих ресурсов;

- расширение сферы охвата операционных действий;

- повышение потенциала и знаний;

- использование более эффективных каналов сбыта;

- создание новых товаров/услуг;

- достижение более высоких уровней эффективности и эффекта масштаба.

Согласно Л. Спинку и Д. Меррилл-Сэндс, успех партнерства объясняется рядом факторов, включающих следующие взаимозависимые элементы, успешная реализация кото-рых позволяет создавать и развивать открытую и доверительную среду:

- четкое видение целей, которые необходимо достичь;

- сильное и общее руководство;
- совместное определение проблемы и подходов ее решения;

- равенство полномочий;

- взаимозависимость и взаимодополняемость;

- разделение ответственности;

- внимание к процессу;

- каналы связи;

- процесс принятия решений;

- доверие, приверженность и признание [52].

Основной предпосылкой ГЧП является выгода, получаемая всеми участвующими сторонами за счет согласования ресурсов и целей. Популярность ГЧП объясняется пониманием того, что такие соглашения могут принести много материальных и ускоренных выгод правительствам стран, частный же сектор получает доступ к новым рынкам и возможностям $[44,45]$.

Инструментами правительственной поддержки могут стать предоставление гарантий, разделение рисков и обязательств, стимулирование инвесторов низкими налогами, недорогими кредитами и прочими льготами. В итоге ГЧП может обеспечить более значительные выгоды, нежели государственная хозяйственная деятельность в инфраструктурных отраслях.

Государственно-частное партнерство в туризме - это, по сути, партнерство между организациями государственного сектора, частным сектором и корпоративными инвесторами с целью разработки концепции, планирования, финансирования, строительства и поставки инфраструктурного оборудования или предоставления услуг. Экономическая комиссия Латинской Америки и Карибского бассейна уточняет, что ГЧП характеризуются разделением рисков, инвестиций, ресурсов, ответственности и вознаграждений. Преимущества государственночастного партнерства в туризме заключаются в следующем:

1) снижение затрат. С помощью ГЧП правительства могут добиться экономии затрат не только при строительстве капитальных проектов, но, что более важно, при эксплуатации и предоставлении услуг;

2) распределение рисков. При ГЧП правительство может разделить риски с частным партнером. В качестве рисков могут выступить: чрезмерные затраты, несоблюдение сроков оказания услуг, трудности с соблюдением экологических норм, недостаточность выручки для оплаты операционных и капитальных затрат и др.; 
3) повышение уровня обслуживания или поддержание текущего уровня обслуживания. ГЧП могут вводить новшества в организацию и предоставление услуг;

4) увеличение доходов. ГЧП может устанавливать ставки для пользователей, которые несут реальные затраты на конкретную услугу. Государственно-частное партнерство также дает возможность внедрять инновационные источники дохода, которые иначе были бы недоступны с помощью традиционных методов предоставления услуг;

5) более высокая эффективность внедрения, которая может быть достигнута за счет комбинации нескольких действий, таких как создание и строительство, более гибкие приобретения и наем, более быстрое утверждение капитального финансирования и принятия решений;

6) другие экономические выгоды. Более активное участие государства в ГЧП может помочь и стимулировать частный сектор, а также способствовать увеличению занятости и экономическому росту.

Касательно рисков, как правило, определяют вероятность следующих моментов:

- утрата государственного контроля. ГЧП по своей природе подразумевают разделение рисков и принятие решений между партнерами. ГЧП, предполагающие значительные инвестиции и риски со стороны частного партнера, часто означают повышение роли партнера в принятии решений по ценам и предоставлении услуги;

- увеличение расходов. При установлении политики цен и сборов для пользователей услуг не все правительства принимают во внимание «истинные» затраты на предоставление услуг. Услуги, предоставляемые через ГЧП, требуют ценовой и налого-ой политики, отражающей полную стоимость;

- политические риски и трудовые вопросы. Многие правительства не имеют опыта в области ГЧП, и это отсутствие знаний о ГЧП со стороны правительств и заинтересованных сторон может привести к большим политическим рискам. Коллективные договоры и трудовое законодательство, применяемые к ГЧП, могут вызвать негативную реакцию со стороны профсоюзов или государственных служащих;

- вопросы ответственности. В случае ГЧП ответственность за предоставление услуг менее ясна для общественности, чем при использовании традиционных методов. Это может привести к публичной критике партнерства, потребовать более активного участия правительства для обеспечения соответствия и реакции на общественные требования;

- небезопасные услуги. Частные партнеры могут пострадать от трудовых споров, финансовых проблем или других обстоятельств, мешающих им выполнять свои обязательства;

- отсутствие конкуренции. Конкуренция ведет к инновациям, эффективности и снижению затрат. Правительства могут не получить выгоду от ГЧП, если имеется ограниченное число потенциальных частных партнеров, обладающих ноу-хау или способностью откликнуться на определенное предложение;

- снижение качества или эффективности обслуживания. Если контракты ГЧП не структурированы должным образом, это может привести к снижению качества обслуживания, неэффективности или отсутствию надлежащего обслуживания проекта;

- несбалансированность в процессе отбора. Традиционные формы предоставления услуг могут создать потенциальные проблемы для правительства, которое можно обвинить в пристрастности при отборе предложений.

Для продвижения конкурентоспособности сектора туризма ГЧП может принимать различные формы, обновляя стратегии в нескольких областях и используя разные инструменты.

Согласно Д. Джексону и П. Мерфи, многие правительства в условиях нехватки рабочих мест в традиционных секторах экономики часто определяют туризм, как возможное средство обеспечения экономического развития [53]. Поэтому наличие прочных отношений между поставщиками и туроператорами является важным условием для привлечения глобальных клиентов и поддержания конкурентоспособности на мировом туристическом рынке. Туристская дестинация предлагает комбинацию продуктов, услуг и впечатлений в четко определенной географической зоне, позволяющую управлять спросом и предложением таким образом, чтобы обеспечить максимальные выгоды для всех заинтересованных сторон. Применение теории стейкхолдеров к любой отрасли предполагает, учет желаний и ожиданий всех заинтересованных сторон, таких как местное сообщество, предприниматели, инвесторы, туристы, туроператоры, посредники и другие заинтересованные группы. Данная теория выступает своего рода нормативным инструментом в планировании развития туризма, который может использоваться для содействия сотрудничеству между основными сторонами, вовлечен- 
ными в данный процесс. Взаимодействие с заинтересованными сторонами подчеркивает важность ресурса партнерства как способа мобилизации различных групп участвующих органов и эффективной координации интересов каждой из них.

Лонг (1997) утверждает, что туристское партнерство представляет собой совокупность совместных усилий между автономными заинтересованными сторонами, которые объединяются в интерактивном процессе, используя общие правила, нормы в ранее созданной организационной структуре в определенной географической зоне [21]. Партнерство между государственным и частным секторами является важным фактором, позволяющим туристским направлениям предлагать качественные продукты, соответствующие/превышающие ожидания потребителей и обеспечивающие успешное и долгосрочное функционирование дестинаций.

Всемирная туристская организация определяет следующие функции и обязанности различных органов, участвующих в государственно-частном партнерстве в сфере туризма (таблица 2) [54].

Таблица 2 - Функции и обязанности государственно-частного партнерства в туризме

\begin{tabular}{|c|c|}
\hline Государственный сектор & Частный сектор \\
\hline Видение туризма & $\begin{array}{l}\text { Понимание экологических и социальных проблем } \\
\text { правительств и местных сообществ }\end{array}$ \\
\hline $\begin{array}{l}\text { Обеспечение благоприятной среды для туризма, } \\
\text { гарантирующей устойчивость и прибыль для частного } \\
\text { сектора, предложение бесплатных потоков капитала и } \\
\text { содействие инвестициям }\end{array}$ & $\begin{array}{l}\text { Развитие навыков и компетенций; доступ к } \\
\text { финансам для развития и эксплуатации туристских } \\
\text { услуг }\end{array}$ \\
\hline $\begin{array}{l}\text { Обеспечение надлежащей инфраструктуры и еe } \\
\text { обслуживания }\end{array}$ & $\begin{array}{l}\text { Ответственность за распространение и применение } \\
\text { отраслевых стандартов с учетом этики, морали и } \\
\text { справедливости }\end{array}$ \\
\hline $\begin{array}{l}\text { Создание достаточных рыночных условий, } \\
\text { стимулирующих устойчивое развитие туризма }\end{array}$ & $\begin{array}{l}\text { Содействие сохранению культуры, традиций и } \\
\text { окружающей среды; руководство образованием и } \\
\text { ориентированием туристов, как фундаментальная } \\
\text { директива для устойчивого развития сектора }\end{array}$ \\
\hline $\begin{array}{l}\text { Наряду со стимулированием обеспечение поддержки, } \\
\text { благоприятных условий и услуг для частного сектора }\end{array}$ & $\begin{array}{l}\text { Вовлечение местных сообществ в развитие туризма } \\
\text { и гарантия удовлетворенности полученными } \\
\text { выгодами }\end{array}$ \\
\hline Обеспечение гибкого трудового законодательства & $\begin{array}{l}\text { Разработка мер по обучению профессиональным } \\
\text { трудовым навыкам для достижения высокого } \\
\text { качества обслуживания }\end{array}$ \\
\hline $\begin{array}{l}\text { Обеспечение стабильного регулирования } \\
\text { справедливой налоговой политики }\end{array}$ & $\begin{array}{l}\text { Сотрудничество с правительством для обеспечения } \\
\text { безопасности и благополучия туристов }\end{array}$ \\
\hline $\begin{array}{l}\text { Обеспечение модели регулирования и защиты } \\
\text { природной, культурной и социальной среды на основе } \\
\text { консультаций со всеми заинтересованными сторонами }\end{array}$ & $\begin{array}{l}\text { Содействие развитию исследований и созданию } \\
\text { статистических баз данных }\end{array}$ \\
\hline $\begin{array}{l}\text { Обеспечение благосостояния местных сообществ, } \\
\text { a также благополучия местных и иностранных } \\
\text { посетителей }\end{array}$ & $\begin{array}{l}\text { Использование технологий, повышающих } \\
\text { эффективность операций, туристский маркетинг и } \\
\text { качество услуг }\end{array}$ \\
\hline $\begin{array}{l}\text { Реализация исследовательской инициативы совместно } \\
\text { с частным сектором для предоставления сообществу } \\
\text { инвесторов информации о рынках отрасли в целях } \\
\text { улучшения восприятия и понимания рыночных } \\
\text { изменений }\end{array}$ & \\
\hline
\end{tabular}

Цели сотрудничества государственных структур и частного сектора в соответствии с различными направлениями деятельности были уточнены Всемирной туристской организацией после проведения исследования, результаты которого были опубликованы в 2002 году (таблица 3) [55]. 
Таблица 3 - Цели в создании партнерских отношений в туризме

\begin{tabular}{|c|c|}
\hline Продукты & Маркетинг и продажи \\
\hline Ценность и сохранение ресурсов & Развитие имиджа дестинации \\
\hline Установление стандартов качества & Развитие эффективности маркетинга \\
\hline $\begin{array}{l}\text { Разработка аттракционов, тематических парков и } \\
\text { мест размещения }\end{array}$ & Расширение масштабов охвата рынков \\
\hline $\begin{array}{l}\text { Обеспечение технической поддержки для разработки } \\
\text { инновационных программ }\end{array}$ & $\begin{array}{l}\text { Обеспечение поддержки маркетинга и электронного } \\
\text { распространения, в том числе через Интернет }\end{array}$ \\
\hline $\begin{array}{ll}\text { Содействие } & \text { экономическому } \\
\text { общества } & \text { благосостоянию } \\
\end{array}$ & Обеспечение поддержки для участия в выставках \\
\hline Обеспечение устойчивого развития туризма & Поддержка интеграции маркетинговых программ \\
\hline Преодоление инвестиционных барьеров & Выход на новые рынки \\
\hline \multicolumn{2}{|l|}{ Защита потребителей } \\
\hline \multicolumn{2}{|l|}{ Развитие конкуренции } \\
\hline Исследования и технологии & Инфраструктура \\
\hline \multicolumn{2}{|c|}{ Предоставление методологий исследований и количественного анализа } \\
\hline Внедрение вспомогательных счетов туризма & Обеспечение общественного здоровья и санитарии \\
\hline \multirow[t]{2}{*}{ Содействие технологическому развитию } & Обеспечение безопасности \\
\hline & Развитие систем связи \\
\hline Человеческие ресурсы & Финансирование \\
\hline Установление стандартов качества и обслуживания & Привлечение инвестиций и финансирование \\
\hline Предложение программ обучения и образования & Влияние на государственные инвестиции \\
\hline Развитие производительности и инноваций & Получение начальных инвестиций \\
\hline
\end{tabular}

С помощью долгосрочных проектов, реализуемых через ГЧП, достигается конкурентоспособность дестинаций. Партнерство между государственным и частным секторами все чаще признается в качестве стратегического ресурса развития туризма. Определение критических факторов успеха этой формы сотрудничества в сфере туризма, имеет фундаментальное значение для его анализа и понимания масштабов. ЮНВТО определила перечень факторов, позволяющих получить более быстрое и правильное представление о принципах, которые должны инициировать и поддерживать сотрудничество в сфере туризма:

- сбалансированная структура с четким распределением ролей и ответственности всех членов;

- распределение лидерских позиций между обоими секторами с общими и четко определенными целями, реалистичными ожиданиями и обеспечением преимуществ обеим сторонам;

- гибкий подход со стороны партнеров, а также желание понять потребности каждого в соответствии с долей ресурсов;

- осведомленность всех партнеров об устойчивом развитии туризма с экономической, социальной и экологической точек зрения;
- долгосрочное обязательство, сочетающее стратегическое видение и планирование с конкретными измеримыми краткосрочными целями;

- периодическая оценка эффективности роли, выполняемой каждым партнером;

- точная и эффективная коммуникация между партнерами и со всеми заинтересованными сторонами [54].

C точки зрения Д. Ким и др., решающими факторами успеха в управлении государственно-частным партнерством в туристском секторе являются: опыт экспертов, обоснованность целей, структура развития партнерства, эффективность партнерских действий и устойчивый характер партнерства [45]. Ряд авторов склонны признать значимость следующих факторов:

- формальность соглашений, устанавливающих партнерство, простоту, основанную на юридических требованиях;

- четкого определения цели, поскольку отсутствие четких целей, отражающих интересы частного сектора, снижает приверженность потенциальных компаний достижению результатов партнерства;

- организационной структуры, т.к. партнерство должно основываться на эффективной координации, требующей соз- 
дание эффективной информационной системы и эффективной сети поддержки $[56,57,58]$.

Определение критических факторов, которые могут повлиять на успех партнерских отношений, имеет важное значение. На основе обобщения теоретических основ государственно-частного партнерства, можно предложить следующую концептуальную модель государственно-частного партнерства, способствующего успешному региональному развитию, которая может стать основой соответствующих тематических исследований (рисунок 2). Центральную позицию в предлагаемой модели занимает процесс государственно-частного партнерства, представляющее определенную систему взаимоотношений стейкхолдеров сферы туризма и основанное на определенных принципах. Государственное управление туризмом играет ключевую роль в разработке устойчивой модели для мест назначения. Правительства являются ключевыми игроками в этом процесce, поскольку оно ответственно за территориальное развитие. Вмешательство и регулирование со стороны государства, особенно на местном уровне, является требованием «эффективной системой управления».

Многие структурные планы по защите и сохранению исторических достопримечательностей требуют руководства со стороны правительства, особенно на местном уровне. Местное управление признано самым авторитетным институтом в разработке эффективной политики развития туризма, потому что именно на местном уровне наиболее четко проявляется влияние развития туризма. Местные власти должны создавать благоприятные условия для эффективного управления развитием туризма. Исследования подтверждают тот факт, что жители, как правило, более восприимчивы к воздействию туризма, при наличии эффективного менеджмента.

Каждое ГЧП, направленное на развитие туристского направления, основано на обеспеченности и доступности туристско-рекреационных ресурсов, степень обеспеченности которыми влияет на успех. Критические факторы успеха основаны на формальности соглашений, четком определении целей, оптимальности организации на основе лидерства и гибкости, коммуникации, а также результативности и эффективности партнерства. Модель представляет собой интерактивную туристскую систему. Сотрудничество во многих сферах туризма развивается в сторону установления формальных партнерских отношений между различными заинтересованными сторонами в государственном и частном секторах (правительством, местными государственными органами, туристской индустрией, инвесторами, местным сообществом, научно-исследовательскими центрами и университетами) и считаются основополагающими для повышения конкурентоспособности деятельности.

Особые требований к туристской зоне, предоставляющей туристские услуги, создают ответственность за результаты деятельности по развитию туризма. Министерство должно выполнять функцию координирующего органа в программах развития туризма страны и нести ответственность за согласованность действий между участниками, положительную связь в организации сотрудничества. На местную администрацию ложится ответственность планирования, организации, и контроля работы всего альянса, разработки инвестиционных программ, представления интересов, маркетинг и т.д. Она может побудить предпринимателей $к$ дальнейшему участию в туристской деятельности после реализации проекта.

Отдельные заинтересованные группы имеют свои собственные интересы. Не следует ожидать, что все участники туристского бизнеса будут вести себя одинаково, поскольку между предпринимателями, местными жителями и приезжими туристами существуют определенные противоречия. Предприятия, связанные с туризмом, могут быть разделены на три - четыре группы по интересам. Даже внутри одной группы (например, среди представителей гостиничных комплексов) могут наблюдаться разные интересы. Так, крупные отели часто не очень заинтересованы в предоставлении курортного обслуживания, так как в них есть все необходимые для организации отдыха гостей. Небольшие же гостиницы, существующие за счет проезжающих туристов, заинтересованы в расширении курортного предложения и организации соответствующих мероприятий. Регулирование взаимоотношений между туристом и жителями дестинации влияет как на оценку дестинации, имидж страны, так и на отношение местного сообщества на развитие туризма в регионе.

Если существует гармония между различными отношениями и переменными, эти аспекты будут способствовать успеху партнерства и, следовательно, будут способствовать региональному развитию туристской отрасли. 


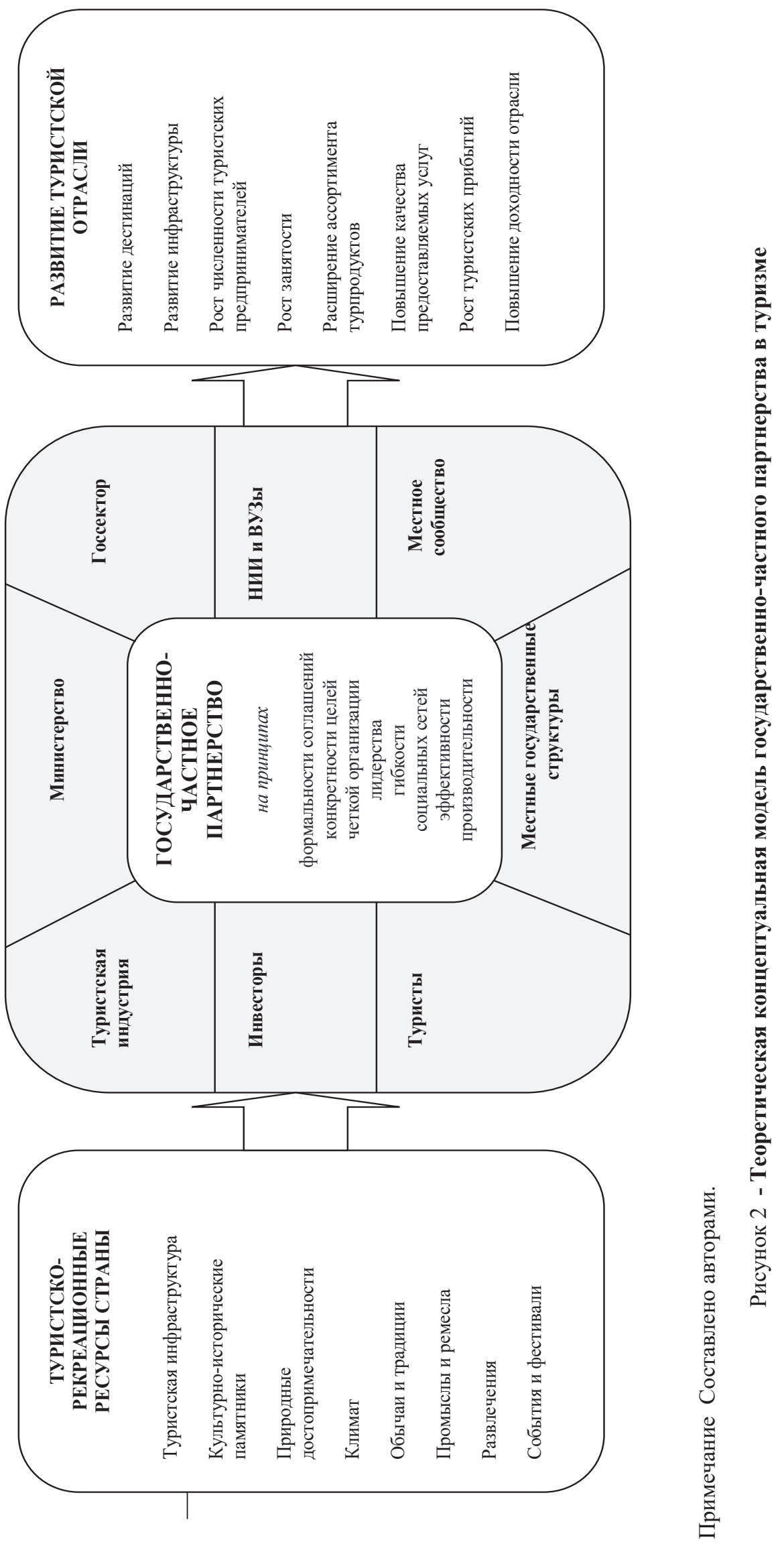




\section{Заключение}

Таким

образом, взаимодействие государства и бизнеса для решения общественно значимых задач становится актуальным в связи с глобализацией, усилением конкуренции на мировом рынке, усложнением социальноэкономических условий, необходимостью обеспечения соответствующего уровня конкурентоспособности отечественных товаров и услуг. Ключевым фактором государственночастного партнерства в туризме является гарантирование выгод от совместного использования ресурсов. Важность партнерства, как способа обеспечения устойчивого развития туристского сектора имеет тенденцию представлять себя как нечто согласованное и очевидное. ГЧП обеспечивает взаимовыгодное сотрудничество его участникам: содействие в выполнении общественно значимых функций для государства и возможность инвестирования в новые объекты - для бизнеса. Однако, неоспоримы и возможные трудности и проблемы, с которыми могут столкнуться участники. Основные угрозы успеха сотрудничества обычно связаны с отсутствием реальных представлений потенциальных партнеров друг о друге и об эффективности его организации. Представленная концептуальная модель государственно-частного партнерства способна выявить имеющиеся пробелы и дать оценку возможностей для конкурентоспособного развития, что поможет стейкхолдерам решить управленческие задачи. Модель применима в дальнейших тематических исследованиях в сфере туризма, а также адаптируема к применению в других сферах экономики при условии соответствующих корректировок.

\section{Список использованных источников}

1. Информационно-правовая система нормативных правовых актов Республики Казахстан. Закон Республики Казахстан о государственночастном партнерстве от 31 октября 2015 года, № 379-V ЗРК. http://adilet.zan.kz/rus/docs/ Z1500000379 (Дата обращения 22.12.2020)

2. Официальный сайт Национальной палаты предпринимателей Республики Казахстан «Атамекен». https://atameken.kz/ru/pages/566gosudarstvenno-chastnoe-partnerstvo (Дата обращения 22.12.2020)

3. Официальный сайт специализированной организации ООН ИКАО. Раздел: Public-Private Partnership (PPP). https://www.icao.int/sustainability/ pages/im-ppp.aspx (Дата обращения 24.12.2020)

4. World bank group. Public-private-partnership legal resource center https://ppp.worldbank.org/publicprivate-partnership/overview/what-are-public-privatepartnerships (Дата обращения 22.12.2020)
5. Официальный сайт издательства Investopedia. https://www.investopedia.com/terms/p/publicprivate-partnerships.asp (Дата обращения 24.12.2020)

6. Public-Private Partnerships and the 2030 Agenda for Sustainable Development: Fit for purpose? [Electronic resource] / K. S. Jomo [et al.] // Department of Economic \& Social Affairs. - DESA Working Paper No. 148 ST/ESA/2016/DWP/148. — 2016. — Mode of access: https://sustainabledevelopment.un.org/content/ documents/2288desaworkingpaper148.pdf (дата обращения 24.12.2020)

7. Официальный сайт Международного валютного фонда https://www.imf. org/en/s e arch\#q=publi c \% 20 private $\% 20$ partnerships\&sort=relevancy (Дата обращения 18.12.2020)

8. APM Group Ltd. https://ppp-certification.com/ ppp-certification-guide/11-defining-ppps-purpose-pppcertification-guide (Дата обращения 24.12.2020)

9. Savas E. S. Privatization and Public Private Partnerships. N. Y.: Chatham House Publishers, 2000. - p. 105-106

10. Klijn E.H., Teisman G.R. Governing PublicPrivate Partnerships: Analyzing and Managing the Processes and Institutional Characteristics of PublicPrivate Partnerships // Public-Private Partnerships: Theory and Practice in International Perspective / Ed. by S. P. Osborne. London: Routledge, 2000. - P. 84-102.

11. Ham H., van Koppenjan J. Building PublicPrivate Partnerships: Assesing and Managing Risks in Port Development // Public Management Review. 2001. - Vol. 3. N 4. - P. 593-616

12. Сайфуллин Р.И. Концепция государственно-частного партнерства в современной экономической системе (методологический подход) // Вектор науки ТГУ. - 2012. - № 4 (22). - С.311-314

13. Государственно-частное партнерство: зарубежный опыт и российские реалии / Ефимова Н.Ф., Маховикова Г.А. - С.-Пб.: Изд-во СПбГЭУ, 2013. - $251 \mathrm{c}$.

14. Ковальчук А.П., Никольская Е.Ю. Реализация принципов государственно-частного партнерства для развития индустрии туризма и гостеприимства в современных условиях в Росии http://www.e-rej.ru/upload/iblock/08e/08ec03dbb268d0 8c984c5828c661e84e.pdf

15. Дерябина М. Государственно-частное партнерство: теория и практика. Вопросы экономики. 2008 (8): c.61-77. https://doi.org/10.32609/0042-87362008-8-61-77

16. Питанов В.А. Государственно-частное партнерство в управлении развитием экономики региона: диссертация ... кандидата экономических наук: 08.00.05 .- Оренбург, 2015.- 204 с.

17. Hodge G., Greve C. Public-Private Partnerships: An International Performance Review // Public Administration Review. - 2007. - June. - P. 37 49.

18. Антонова К.А. Государственно-частное партнерство как фактор социально-экономического развития России : диссертация ... кандидата экономических наук : 08.00.05.- Москва, 2012.- 213 с.: ил. РГБ ОД, 61 12-8/1921 
19. Болехов И.Е. Государственно-частное партнерство, как признак инновационной экономики // Креативная экономика. - 2012. - Том 6. № 9. - С. 120-125

20. Ларин С.Н. Государственно-частное партнерство: зарубежный опыт и российские реалии // Государственно-частное партнерство в инновационных системах / Под общ. ред. С.Н. Сильвестрова. - М.: Издательство ЛКИ, 2008. - 312 с.

21. Long, P. Researching tourism partnership organizations: from practice to theory to methodology. In: MURPHY, P. (Ed.). Quality Management in Urban Tourism. Chichester: Wiley, 1997. - p.235-251.

22. Kernagham, K. Partnership and public administration: conceptual and practical considerations. // Canadian Public Administration. - 1993. - v.36, p.5776.

23. Witt S.; Moutinho L. Tourism marketing and management handbook. New York: Prentice Hall International, 1995.

24. В.Варнавский. Государственно-частное партнерство: некоторые вопросы теории и практики // Мировая экономика и международные отношения. - 2011. - № 9. - C.41-50. https://www. imemo.ru/files/File/ru/publ/2011/11046.pdf

25. Белицкая А.В. (2012) Правовое регулирование государственно-частного партнерства. - М.: Статут. - 191 с

26. PPP Knowledge Lab https://pppknowledgelab. org/guide/sections/1-introduction (Дата обращения 18.12.2020)

27. Официальный сайт Минэкономразвития России. https://www.economy.gov.ru/ (Дата обращения 25.12.2020)

28. Резниченко Н.В. Модели государственночастного партнерства // Вестник С.-Петерб. ун-та. Сер. Менеджмент. - 2010. - Вып. 4. - С.58-83

29. Сытых М.С. Государственно-частное партнерство - перспективный инструмент реализации проектов в социальной сфере в РФ (на примере Томской области). Национальный исследовательский Томский политехнический университет (ТПУ). - Томск, 2017.

30. Пилякина В.С. Механизмы ГЧП в банковском проектном финансировании в России // Современная экономика: проблемы и решения. 2009. - № 12. - C. 13-17.

31. Кабашкин В.А. Государственно-частное партнерство в регионах Российской Федерации: учебное пособие. - М.: Дело, 2010

32. Akintoye A., Beck M., Hardcastle C. Public-Private Partnerships: Managing Risks and Opportunities. Oxford, UK; Malden, MA: Blackwell Science, 2003.

33. Meidutē I.; Paliulis, N.K. Feasibility study of public-private partnership, International Journal of Strategic Property Management, 2011. - pp.264-266

34. Chapman M. Effective partnership working: good practice note 1. Edinburgh: Scottish Office, 1998.

35. Сазонов В.Е. Государственно-част-ное партнерство: гражданско-правовые, административно-правовые и финансово-правовые аспекты. М.: Буки Веди, 2012. - 492 с.
35. Государственно-частное партнерство в условиях инновационного развития экономики [Монография] / Под ред. А.Г. Зельднера, И.И. Смотрицкой. - М.: ИЭ РАН, 2012. - С. 212.

36. Gerrard M. B. Public-Private Partnerships: What Are Public-Private Partnerships, and How Do They Differ from Privatizations? // Finance \& Development. 2001. - Vol. 38. N 3. - P. 48-51.

37. Building Better Partnerships the final Report from the Commission on Public Private Partnerships. June 2001 ISBN 1860301584 https://www.ippr.org/files/ images/media/files/publication/2011/05/cppp_1234.pdf

38. Алпатов А.А., Пушкин А.В., Джапаридзе Р.М. Государственно-частное партнерство: Механизмы реализации. - М.: Альпина Паблишерз, 2010. $196 \mathrm{c}$.

39. Grimsey D., Lewis M. K. The Economics of Public Private Partnerships. Cheltenham, UK: Edward Elgar, 2005.

40. Бруссер П., Рожкова С. Государственночастное партнерство - новый механизм привлечения инвестиций // Рынок ценных бумаг. - 2007. - № 2.

41. Дынин Е. А. Риски бизнеса в частногосударственном партнерстве // Общество и экономика. - 2007. - № 5-6. - С. 111.

42. Амерханова А.Б. Диссертации на соискание ученой степени доктора философии (PhD) на тему: «Экономические механизмы согласования интересов в государственно-частном партнерстве (на материалах Республики Казахстан)» по специальности 6D050600 - «Экономика». Диссертация выполнена на кафедре «Экономика» в Павлодарском государственном университете имени С.Торайгырова. 2015 г.

43. Государственно-частное партнерство: Основные принципы финансирования / Э.Р.Йескомб. Пер. с англ.- М.: Альпина Паблишер, 2015.— 457 с.

44. Partnering for the future - public-private partnerships in tourism development. Investment \& Development Office, Ministry of Tourism, Culture \& Recreation, Province of Ontario, Canada, 2002.

45. Kim D.; Kim C.; Lee T. Public and private partnership for facilitating tourism investment in the Apec Region. APEC Tourism Working Group (TWG) \& Ministry of Culture and Tourism, Republic of Korea, Asia-Pacific Economic Cooperation, 2005.

46. Linder S. Coming to terms with public private partnerships: a grammar of multiple meanings. // American Behavioral Scientist. - 1999. - v.43, n.1. P.35-51.

47. De Lacy T.; Battig M.; Moore S.; Noakes S. (2002) Public / Private Partnerships for Sustainable Tourism. Delivering a Sustainability Strategy for Tourism Destinations. CRC for Sustainable Tourism. Griffith University, PMB 50, GOLD COAST MC QLD 9726, AUSTRALIA, JULY 2002.

48. Хлунов А.В. Государственно-частное партнерство как механизм реализации государственнной инновационной политики в РФ. ИННОВАЦИИ № 1 (88), 2006, С.7-10

49. Țigu G., Călărețu V. B., Daniel B. PublicPrivate Partnership - a new path for tourism development. https://www.academia.edu/2386259/ 
Public Private Partnership a new path for Дата обращения: $2 \overline{9} .12 .2020$.

50. Daniela Voicu, Cristina Voicu-Olteanu. Advantages And Limitations Of The Public Private Partnerships And The Possibility Of Using Them In Romania, Transylvanian Review of Administrative Sciences, 2009. - P. 189-198.

51. Vining A., Boardman A.E. Public-Private Partnerships in Canada: Theory and Evidence// Canadian Public Administration. - 2008. - № 51(1). P. 9-44. DOI:10.1111/j.1754-7121.2008.00003.x/ Дата обращения: 03.01.2021.

52. PERRY C.; GO, F. Partnerships in international travel and tourism marketing: a systems-oriented approach between Australia, New Zealand, Germany and the United Kingdom. Journal of Travel \& Tourism Marketing. - 2001. - v.11, n.1. - P.59-77.

53. Jackson J.; Murphy P. Tourism destinations as clusters: analytical experiences from the New World. // Tourism and Hospitality Research. - 2002. - v.4, n.1. p.36-52.

54. World Tourism Organization. Publicprivate sector cooperation - enhancing tourism competitiveness. Madrid, 2000, 289 p. https://www.eunwto.org/doi/pdf/10.18111/9789284417438. (Дата обращения: 27.12.2020).

55. World Tourism Organization. Cooperation and partnerships in tourism: a global perspective. Madrid, 2003. https://www.e-unwto.org/doi/ pdf/10.18111/9789284406012 )Дата обращения: 27.12.2020).

56. Augustyn M., Knowles T. Performance of tourism partnerships: a focus on York. //Tourism Management. - 2000. - v.21. - P.341-351.

57. Augustyn M. Marketing tourism regions: effectiveness through cooperation. In: RICHARDS, G. (Ed.). Tourism in Central and Eastern Europe: education for quality. [S.1]: Tilburg University Press, 1996. - P.261-274.

58. Stoner J.; Freeman R. Management. Englewood Cliffs, New York: Prentice-Hall, 1992. - 732 p.

\section{References}

1. Information and legal system of normative legal acts of the Republic of Kazakhstan. Law of the Republic of Kazakhstan on public-private partnership dated October 31, 2015 No. 379-V. http://adilet.zan.kz/ rus/docs/Z1500000379 (Date of access 22.12.2020)

2. Official site of the National Chamber of Entrepreneurs of the Republic of Kazakhstan «Atameken». https://atameken.kz/ru/pages/566gosudarstvenno-chastnoe-partnerstvo (Date of access 22.12.2020)

3. Official site of the UN specialized organization ICAO. Section: Public-Private Partnership (PPP). https://www.icao.int/sustainability/pages/im-ppp.aspx (Date of access 24.12.2020)

4. World bank group. Public-private-partnership legal resource center https://ppp.worldbank.org/publicprivate-partnership/overview/what-are-public-privatepartnerships (Date of access 22.12.2020)
5. Investopedia official website. https://www. investopedia.com/terms/p/public-private-partnerships. asp (Date of access 24.12.2020)

6. Public-Private Partnerships and the 2030 Agenda for Sustainable Development: Fit for purpose? [Electronic resource] / K. S. Jomo [et al.] // Department of Economic \& Social Affairs. - DESA Working Paper No. 148 ST/ESA/2016/DWP/148. — 2016. — Mode of access: https://sustainabledevelopment.un.org/content/ documents/2288desaworkingpaper148.pdf (дата обращения 24.12.2020)

7. Official website of the International Monetary Fund https://www.imf.org/en/search\#q=public\% $\% 20$ private $\% 20$ partnerships\&sort=relevancy (Date of access 18.12.2020)

8. APM Group Ltd. https://ppp-certification.com/ ppp-certification-guide/11-defining-ppps-purpose-pppcertification-guide (Date of access 24.12.2020)

9. Savas E. S. (2000) Privatization and Public Private Partnerships. N. Y.: Chatham House Publishers, p. $105-106$

10. Klijn E.H., Teisman G.R. (2000) Governing Public-Private Partnerships: Analyzing and Managing the Processes and Institutional Characteristics of PublicPrivate Partnerships // Public-Private Partnerships: Theory and Practice in International Perspective / Ed. by S. P. Osborne. London: Routledge, P. 84-102

11. Ham H., van, Koppenjan J. (2001) Building Public-Private Partnerships: Assesing and Managing Risks in Port Development // Public Management Review. Vol. 3. N 4. P. 593-616

12. R.I. Sayfullin (2012) The concept of publicprivate partnership in the modern economic system (methodological approach). TSU science vector. No. 4 (22), P.311-314

13. Public-private partnership: foreign experience and Russian realities / Efimova N.F., Makhovikova G.A. - S.-Pb .: Publishing house of SPbGEU, 2013 . - 251 p.

14. Kovalchuk A.P., Nikolskaya E.Yu. Implementation of the principles of public-private partnership for the development of the tourism and hospitality industry in modern conditions in Russia http://www.e-rej.ru/upload/iblock/08e/08ec03dbb268d0 8c984c5828c661e84e.pdf

15. Deryabina M. Public-private partnership: theory and practice. Economic issues. 2008 (8): p.61-77. https://doi.org/10.32609/0042-8736-2008-8-61-77

16. V.A. Pitanov (2015) Public-private partnership in managing the development of the regional economy: dissertation ... candidate of economic sciences: 08.00.05 / Pitanov Valery Aleksandrovich. [Place of defense: Orenburg State University] .- Orenburg, 2015.- 204 p.

17. Hodge G., Greve C. (2007) Public-Private Partnerships: An International Performance Review // Public Administration Review. June. P. 37-49.

18. Antonova K.A. (2012) Public-private partnership as a factor of socio-economic development of Russia: dissertation ... Candidate of Economic Sciences: 08.00.05 / Antonova Kira Aleksandrovna; [Place of protection: Financial University under the Government of the Russian Federation] .- Moscow, 2012.- 213 p .: ill. RSL OD, 61 12-8 / 1921 
19. Bolekhov I.E. (2012) Public-private partnership as a sign of an innovative economy // Creative Economy. - 2012. - Volume 6. - No. 9. - P. 120-125

20. Larin S.N. (2008) Public-private partnership: foreign experience and Russian realities / S.N. Larin // Public-private partnership in innovation systems / Ed. ed. S.N. Silvestrova. - M .: Publishing house LCI, 2008. - 312 p., P. 51-62

21. Long P. (1997) Researching tourism partnership organizations: from practice to theory to methodology. In: MURPHY, P. (Ed.). Quality Management in Urban Tourism. Chichester: Wiley, p.235-251.

22. Kernagham K. (1993) Partnership and public administration: conceptual and practical considerations. Canadian Public Administration, v.36, p.57-76.

23. Witt S.; Moutinho L. (1995) Tourism marketing and management handbook. New York: Prentice Hall International.

24. Varnavsky V. (2011) Public-private partnership: some questions of theory and practice / World economy and international relations, no. 9, p.41-50 https://www. imemo.ru/files/File/ru/publ/2011/11046.pdf

25. Belitskaya A.V. (2012) Legal regulation of public-private partnership. - M .: Statute. - $191 \mathrm{p}$.

26. PPP Knowledge Lab https://pppknowledgelab. org/guide/sections/1-introduction (Date of access 18.12.2020)

27. Official website of the Ministry of Economic Development of Russia. https://www.economy.gov.ru/ (Date of access 25.12.2020)

28. Reznichenko N.V. (2010) Models of publicprivate partnership. Bulletin of St. Petersburg. un-that. Ser. Management. Issue 4.P.58-83

29. Sytykh M.S. (2017) Public-private partnership is a promising tool for the implementation of projects in the social sphere in the Russian Federation (on the example of the Tomsk region). National Research Tomsk Polytechnic University (TPU). Tomsk, 2017.

30. Pilyakina V.S. (2009) PPP mechanisms in bank project financing in Russia // Modern economy: problems and solutions. - No. 12. - P. 13-17.

31. Kabashkin V.A. (2010) Public-private partnership in the regions of the Russian Federation: textbook / Kabashkin V.A. M .: Delo, 2010.

32. Akintoye A., Beck M., Hardcastle C. (2003) Public-Private Partnerships: Managing Risks and Opportunities. Oxford, UK; Malden, MA: Blackwell Science, 2003.

33. Meidutē I.; Paliulis N.K. (2011) Feasibility study of public-private partnership, International Journal of Strategic Property Management, pp.264-266/

34. Chapman, M. (1998) Effective partnership working: good practice note 1. Edinburgh: Scottish Office.

35. Sazonov V.E. (2012) Public-private partnership: civil law, administrative legal and financial legal aspects. - M .: Buki Vedi, 2012 .-- 492 p.

35. Public-private partnership in the context of innovative economic development [Monograph] / Ed. A.G. Zeldner, I.I. Smotritskaya. Moscow: IE RAN, 2012.S. 212.

36. Gerrard M. B. (2001) Public-Private Partnerships: What Are Public-Private Partnerships, and
How Do They Differ from Privatizations? // Finance \& Development. Vol. 38. N 3. P. 48-51.

37. Building Better Partnerships the final Report from the Commission on Public Private Partnerships. June 2001 ISBN 1860301584 https://www.ippr.org/files/ images/media/files/publication/2011/05/cppp_1234.pdf

38. Public-private partnership: Implementation mechanisms / A. A. Alpatov, A. V. Pushkin, R. M. Dzhaparidze. - M .: Alpina Publishers, 2010 .- 196

39. Grimsey D., Lewis M. K. (2005) The Economics of Public Private Partnerships. Cheltenham, UK: Edward Elgar.

40. Brusser P. (2007) Public-private partnership - a new mechanism for attracting investments / P. Brusser, S. Rozhkova // Securities market. - No. 2.

41. Dynin E.A. (2007) Business risks in publicprivate partnership // Society and Economics. - No. 5-6. - P. 111.

42. Amerkhanova A.B. Dissertations for the degree of Doctor of Philosophy (PhD) on the topic: "Economic mechanisms for reconciling interests in public-private partnerships (based on the materials of the Republic of Kazakhstan)" in the specialty 6D050600 - "Economics". The thesis was completed at the Department of Economics at S. Toraigyrov Pavlodar State University. 2015

43. Public-private partnership: Funding principles / E.R.Yescombe; Per. from English.— M .: Alpina Publisher, 2015.- $457 \mathrm{p}$.

44. Partnering for the future - public-private partnerships in tourism development. Investment \& Development Office, Ministry of Tourism, Culture \& Recreation, Province of Ontario, Canada, 2002.

45. Kim D.; Kim C.; Lee T. (2005) Public and private partnership for facilitating tourism investment in the Apec Region. APEC Tourism Working Group (TWG) \& Ministry of Culture and Tourism, Republic of Korea, Asia-Pacific Economic Cooperation.

46. Linder S. (1999) Coming to terms with public - private partnerships: a grammar of multiple meanings. American Behavioral Scientist, v.43, n.1, p.35-51.

47. De Lacy T.; Battig M.; Moore S.; Noakes S. (2002) Public / Private Partnerships for Sustainable Tourism. Delivering a Sustainability Strategy for Tourism Destinations. CRC for Sustainable Tourism. Griffith University, PMB 50, GOLD COAST MC QLD 9726, AUSTRALIA, JULY 2002.

48. Khlunov A.V. (2006) Public-private partnership as a mechanism for the implementation of state innovation policy in the Russian Federation. INNOVATIONS No. 1 (88), 2006, P.7-10

49. Țigu G., Călărețu V. B., Daniel B. PublicPrivate Partnership - a new path for tourism development. https://www.academia.edu/2386259/ Public_Private_Partnership_a_new_path_for_Date of access: 29.12.2020.

50. Daniela Voicu, Cristina Voicu-Olteanu (2009) Advantages And Limitations of The Public Private Partnerships And The Possibility Of Using Them In Romania, Transylvanian Review of Administrative Sciences, pp. 189-198.

51. Vining A., Boardma A.E. . (2008) PublicPrivate Partnerships in Canada: Theory and Evidence// Canadian Public Administration 51(1):9 - 44. 
DOI:10.1111/j.1754-7121.2008.00003.x/ Date of access: 03.01.2021.

52. PERRY C.; GO F. (2001) Partnerships in international travel and tourism marketing: a systemsoriented approach between Australia, New Zealand, Germany and the United Kingdom. Journal of Travel \& Tourism Marketing, v.11, n.1, p.59-77.

53. Jackson J.; Murphy P. (2002) Tourism destinations as clusters: analytical experiences from the New World. Tourism and Hospitality Research, v.4, n.1, p.36-52.

54. World Tourism Organization. Publicprivate sector cooperation - enhancing tourism competitiveness. Madrid, 2000, 289 p. https://www.eunwto.org/doi/pdf/10.18111/9789284417438. Дата обращения: 27.12.2020.
55. World Tourism Organization. Cooperation and partnerships in tourism: a global perspective. Madrid, 2003. https://www.e-unwto.org/doi/ pdf/10.18111/9789284406012 Дата обращения: 27.12.2020.

56. Augustyn M., Knowles, T. (2000) Performance of tourism partnerships: a focus on York. Tourism Management, v.21, p.341-351.

57. Augustyn M. (1996) Marketing tourism regions: effectiveness through cooperation. In: RICHARDS, G. (Ed.). Tourism in Central and Eastern Europe: education for quality. [S.1]: Tilburg University Press, p.261-274.

58. Stoner J.; Freeman R. (1992) Management. Englewood Cliffs, New York: Prentice-Hall, 1992, 732 p.

\section{Сведения об авторах}

Тлеубердинова А.Т. - корреспондирующий автор, доктор экономических наук, главный научный сотрудник РГКП «Институт экономики» Комитета науки Министерства образования и науки Республики Казахстан, Казахстан, 050000, г. Алматы, Курмангазы 29, 87014394931, tat404@mail.ru, код ORCID 00000001-8762-5932, ResearcherID AAQ-1109-2020

Алдабергенова А.Т. - докторант 1-го курса по специальности «Государственное и местное управление», Карагандинский экономический университет Казпотребсоюза, 100000, ул. Академическая 9, Караганда, 87012319959, aigolek_09.87@mail.ru, код ORCID 0000-0001-5860-9589 Researcher ID : UAAB-3590-2019

Салауатова Д.М. - магистр наук, старший преподаватель кафедры «Экономика и предпринимательство», Карагандинский экономический университет Казпотребсоюза, 100000, ул. Академическая 9, Караганда, 87015803674, Di_kz010@mail.ru, код ORCID 0000-0001-8569-3755, Researcher ID : U-5859-2018

\section{Information about the authors}

Aizhan Tleuberdinova - corresponding author, Doctor of Economic Sciences, Institute of Economics Science Committee of the Ministry of Education of the Republic of Kazakhstan, 050000, Almaty, Kurmangazy 29, 87014394931, tat404@mail.ru, код ORCID 0000-0001-8762-5932, ResearcherID AAQ-1109-2020

Aigul Aldabergenova - 1st year doctoral student in the specialty «State and local administration», Karaganda Economic University of Kazpotrebsouz, 100000, Academic 9, Karaganda, 87012319959, aigolek_09.87@mail.ru, код ORCID 0000-0001-5860-9589 Researcher ID : UAAB-3590-2019

Dinara Salauatova - Master of Science, Senior Lecturer of the Department of Economics and Entrepreneurship, Karaganda Economic University of Kazpotrebsouz, 100000, Academic 9, Karaganda, 87015803674, Di_kz010@ mail.ru, код ORCID 0000-0001-8569-3755, Researcher ID : U-5859-2018

Дата поступления рукописи: 19.01.2021

Прошла рецензирование: 25.02.2021

Принято решение о публикации: 07.03.2021

Received: 19.01 .2021

Reviewed: 25.02.2021

Accepted: 07.03.2021

Қарастыруға қабылданды: 19.01.2021

Рецензиялауды өтті: 25.02.2021

Жариялауга қабылданды: 07.03.2021 